IFAS Extension

\title{
Facts About Vitamin B6 ${ }^{1}$
}

Anne Kendall ${ }^{2}$

\section{Why Do We Need Vitamin B6?}

Vitamin B6, also called pyridoxine, is a water-soluble vitamin needed to break down the protein we eat. This vitamin is used by our bodies to make important proteins, and it helps our muscles use energy. It also helps make brain chemicals that tell the systems in our bodies what to do.

\section{What Happens If We Don't Get Enough Vitamin B6?}

People who don't get enough vitamin B6 in their diets may have skin problems or anemia. More severe symptoms of deficiency include mental confusion depression, and convulsions. The immune system may also be affected, making it more difficult to fight disease.

Vitamin B6 deficiency is rare because this vitamin is found in many common foods. Groups at risk for B6 deficiency include people with impaired kidney function or autoimmune disorders such as rheumatoid arthritis. Diseases that cause malabsorption, such as celiac disease, Crohn's disease, or ulcerative colitis, can also increase risk for a B6 deficiency. Heavy alcohol use and use of certain medications, such as cycloserine, anti-epileptic medications, and theophylline, can cause low levels of B6 in the blood.

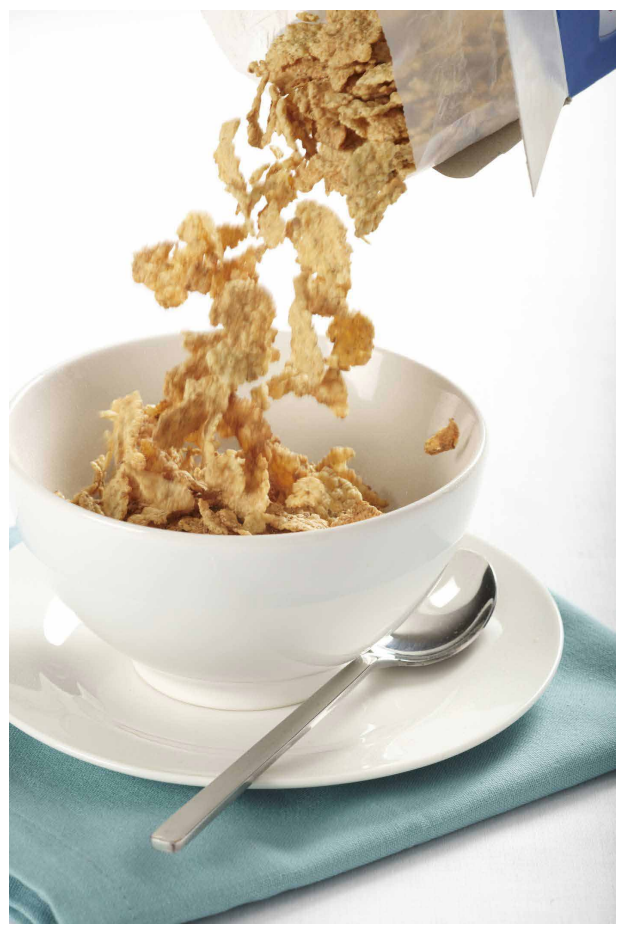

Figure 1. Fortified breakfast cereals are one of the best sources of vitamin B6.

Credits: iStockphoto

\section{How Much Vitamin B6 Do We Need?}

Table 1 lists the Recommended Dietary Allowance (RDA) of vitamin B6 for adults. Older adults need slightly more vitamin $\mathrm{B} 6$ in their diets. Women who are pregnant or breastfeeding also have higher vitamin B6 needs.

1. This document is FCS8700, one of a series of the Department of Family, Youth and Community Sciences, UF/IFAS Extension. Publication date: July 2006. Latest revision: July 2013. Please visit the EDIS website at http://edis.ifas.ufl.edu.

2. Anne Kendall, PhD, RD, LD/N, senior lecturer, Food Science and Human Nutrition Department, UF/IFAS Extension, Gainesville, FL 32611. 
Table 1.

\begin{tabular}{|l|c|}
\hline Life Stage & Amount (mg*/day) \\
\hline Adults, ages 19-50 & 1.3 \\
\hline Men, ages 51+ & 1.7 \\
\hline Women, ages 51+ & 1.5 \\
\hline Pregnancy & 1.9 \\
\hline Lactation & 2.0 \\
\hline *mg = milligrams of vitamin B6 \\
\hline
\end{tabular}

\section{How Can We Get Enough Vitamin}

\section{B6?}

One of the best sources of vitamin B6 in the diets in the United States is fortified ready-to-eat cereal. Look for the word "pyridoxine" in the ingredient list on the Nutrition Facts label to see if vitamin B6has been added.

Other rich sources of vitamin B6 are beef liver and other organ meats. Good sources include meat, fish, and poultry, and starchy vegetables such as potatoes, plantains, and winter squash.

Table 2. Food sources of vitamin B6

\begin{tabular}{|l|c|}
\hline Food & $\begin{array}{c}\text { Vitamin B6 } \\
\text { (mg/serving) }\end{array}$ \\
\hline Fortified cereal, 1 cup & $0.5-2.0$ \\
\hline Beef liver, cooked, $3 \mathrm{oz}$ & 0.9 \\
\hline Salmon, cooked, 3 oz & 0.6 \\
\hline Chicken breast, cooked, 3 oz & 0.5 \\
\hline Potato, baked, with skin, 1 medium & 0.5 \\
\hline Beef, top sirloin, cooked, 3 oz & 0.5 \\
\hline Banana, 1 medium & 0.4 \\
\hline Spinach, cooked, 1 cup & 0.4 \\
\hline Winter squash, cooked, 1 cup & 0.3 \\
\hline oz = ounce, mg = milligrams & \\
\hline
\end{tabular}

\section{What About Supplements?}

Most multivitamins include vitamin B6. However, most people in the United States get plenty of vitamin B6 from their diet, making additional supplements unnecessary.

\section{How Much Is Too Much?}

No problems are known from eating large amounts of vitamin B6 in foods. However, taking large doses of vitamin B6 in supplements can cause nerve damage. This can be so severe that walking is impossible. Nerve damage from excess vitamin B6 can be permanent. If you take a supplement, do not take more than $100 \%-150 \%$ of the Daily
Value for vitamin B6 per day. Keep your total vitamin B6 intake less than $100 \mathrm{mg} /$ day from food and supplements combined.

\section{Where Can I Get More Information?}

The Family and Consumer Sciences (FCS) agent at your county UF/IFAS Extension office may have more information or nutrition classes for you to attend. Also, a registered dietitian $(\mathrm{RD})$ can provide reliable information.

Reliable nutrition information may be found at the following sites:

- National Institutes of Health - Dietary Supplement Fact Sheet: Vitamin B6: http://ods.od.nih.gov/factsheets/ VitaminB6-QuickFacts/

- UF/IFAS Extension: http://solutionsforyourlife.ufl.edu

- USDA National Agricultural Library: http://fnic.nal. usda.gov/

- Nutrition.gov: http://www.nutrition.gov 